\title{
VI. New outlines of chemical philosophy
}

\section{Ez. Walker Esq.}

To cite this article: Ez. Walker Esq. (1814) VI. New outlines of chemical philosophy , Philosophical Magazine, 43:189, 22-26, DOI: 10.1080/14786441408637961

To link to this article: http://dx.doi.org/10.1080/14786441408637961

曲 Published online: 27 Jul 2009.

Submit your article to this journal

Џ Article views: 4

Q View related articles $\sqsubset$ 
Independent of this circumstance, it is amusing to find an individual so confident of the infallibility of his own observations, as to consider them suffeient to subvert the experience of Canton, Franklin, Wilke, Epims, Cavallo, Stanhope, and Robison; although the observations of the most experienced electricians of the present time are opposed to the inference he has drawn.

Londot, Jan. 10, 1:14.

G. J. Singer.

To Messrs. Nicholson and Tilloch.

VI. New Ouilines of Chemical Philosophy., By Ez. WaLKER, Esq. of Lynn, Norfolk.

[Continued from p. 371, vol. xiii.]

$M_{\text {Ucr }}$ confusion in chemical philosophy seems to arise from want of precision in chemical language. Oxygen and hydrogen are terms that are used in a very vague manner, no distinction being made between oxygen and oxygen gas, nor between hydrogen and hydrogen gas. P'asitive and negative are words that have no definite meanings in chenical science; and yet we have positive and negative electricity, positive and negative galvanism; and even the laws of chiemical affinity are now explained by the terms positive and negative. We have also fixed fire, phlogiston, and other words that express things rather more imaginary than real. All this confusion might be avoided by adopting two new terms to express the two elements, which produce effects that are real objects of our senses, and by which those elements may be known in all their various conbinations with matter.

"Mr. Davy," now Sir Humphry Davy, "exhibited the powers of the Voltaic instrument by briliant experiments ; metals were fused upon the surface of water and of oil of turpentine, and burnt in contact with them. He stated that the maximum of heat was at the positive electrical strface; and he exhibited an experiment in which, though the most brilliant light was at the negative surface, yet the ignition was infinitely greater at the positive*."

From these properties of the two elements above mentioned, that element which produces the maximum of heat, at the positive electrical surface, may be called the generator of heat, or thermogen; and that element which appears at the negative surface, and exhibits the most brilliant light, may be called the generator of light, or photogen. The choice of these terms seems to be sanctioned by the words thermometer and photometer now in common use. By the term photogen is to be understood the imponderable element of all combustibles, whether it * Phil. Mag. vol. xxxix. p. 187.

exists 
exists combined or uncombincd with matter; by thermagen is to be understood the imponderaljle element of all supporrers of combustion, whether it exists combined witi matter, or in a free and uncombined state.

\section{Thermogen and Photogen.}

When a Leyden jar is receiving a charge from an electric machine, one side receives thermogen from the atmosphere, and the other side receives photogen from the earth. When a communication is made between the inside and the outside of the jar, by some conductor of these elements, the element from the inside attracting the element from the outside, a spark is produced, consisting of a double current exhibiting both light and heat, and the equilibrium which was destroyed by the action of the machine is restored. But it cannot be supposed thiat these elements are annihilated by their union: such a supposition would be absurd: they only enter into new combinations, and return again into those receptacles from whence they were withdrawn. For while the element of one side of the jar goes to the earth, the element of the other side is conmunicated to the air.

When two portions of the same element are nearly equal they repel each other, but when they are very unequal they attract each other. This is known from an infrite number of experiments : consequently, the immense attraction oi the photogin in the earth attracts any small portion of the same element, which may be disengaged from its base, with an infnite foree; and the thermogen in the atmosphere attracts every siaall portion of the same element the instant that it is disengageth from matter.

But why does not the thermogen in the atrnosphere unite with the photogen of the earth, as they have a very strong attraction for each other ? This question will be easily solved as scon as it is understood that they are kept asunder by their bases. Oxygen and hydrogen gases mixed together in a proper vessel, would remain for ages without produeing any effect upon one another; but let their elements be brought into contact, either by pressure or increase of temperature, and combustion will instantly talie place.

If the attraction between these elements of combution aud their bases were not proportioned to a mathematical exactness, the whole veconomy of our globe would be deranged. For, if this attraction were greater than it is at present, we should have perpetual frost; and if this attraction were much less than it is, all combustibles wonld be reduced to ashes in a moment : but, in the present state of things, it is impossible that either of these events should happen.

It is not to be understood that photogen is light, or that B 4 thermogen 
thomogen is heat; they are the gencrators of light and heat, hicht ard heat being the effects which they produce on matter. The thermogen on the imide of a charged jar camot be felt, nor does it produce any effect unon the most delieate thermometer, nor is any light perecptible on the outside of the jar. Jut let tie jar be discharged through a piece of irn wire, and both light and heat are prosured. When the metal becomes red hot by this means, it loses it; photogur, attrats oxygen gas from the air, and becomes oxitizol. If this oxite be mixet with some matter entaning piotoger, and iscat applied, oxygen gas will be reproduced, and the metal will receive photogen, and again become malleable.

The applicution of these chements, to elucilate some of the most interestiing phxnoncia in nature, will be more fully treated of hereaiter.

\section{Composition of Water.}

Some philosophers maintain that water is a simple body, and the only ponderable basis of oxygen and hydrogen gases, and other acrial fluids; but others suppose that water is a compound of oxygen and hydrogen, and this opinion is now generally adopted by writers on chemistry. But all the experiments made to separa: the component parts of water, tend to prove that it is a boty simple and undecompounderl. What has led men to conchide that water is a compound body, seems to luave arisen from their supposing that the electric spark is a simple fuid; but as it is now well lnown that it conists of two elements possessing different properties, both chemical and mechanical*, the passing of these elcincnts tinrough water is no proof of its being a compound stibstance, nowithstanding oxygen and hydrogen gases are produced by this means.

When themogen and photogen pass through water in contrary directions, thermcgen and water form oxygen gas ; photogen an? waier form hyrrogen gas. These gases being mixed together in a close glass vasel, and their tempcrature increased to a certain demref, combustion takes place, light and heat escape through the ghass, and the produet is pure water.

That thermogen fand photogen are capable of producing combustion, bewre they entereri the water, is unquestionable, nor can it he supposed that they are anmihilated by passing through it; for they aryear again in the two gases, producing the same phanonera of if $x^{2}$ and heat as before. Hence it appears that the two detuenes whin's compose the electric spark are the imponderable eliments of the two gasss, and that water is their common base. Oxuon and hylusgen gases thrown upon fire pro-

$$
\text { * Plil. Miag. vol. xli. p. } 161 .
$$


duce the most intense hant; but water being thrown upon fire extinguisles it: water, therefore, is neither a combustible nor a supporter of combustion, and consequenty it contains neituer oxygen nor hylrogen.

Another experiment, which has bean mide to prove that water is a compoind of axyen and hylrogen, consists of passing stean through a red hot iron tuhe containing turnings of iron, by whic! mean; hydrogen gas is produced, and the iron turnings becone oxidizad; whence it is concluded, that water is a compound of oxygen and hylrogen. But let the experiment be tried with a red hot glass tube containing pieces of broken glass, and no hydrogrn gas will aprear: hence it is evidory, that one of the component parts of the hydiogen gas, in the former experiment, came from the metal.

Now wien the turnings of iron become red hot, the photogen they contain and water produce hydrogen gas: but in this process thermogen must be present, for no combustion nor increase of temperature cal be gensatid unless thermogen and photogen be united. The most condensed rays of the sun do not exaite combustion in racuo, nor in any gas deprived of oxygen, even when the most intiammable substance is cmployed ${ }^{*}$. Consequenty, the thermogen and water prorluce oxygen gas, which the iron, after being deprived of its photogen, attracts, and becomes an oxide of that metal.

This experiment may be illustrated by the huming of iron wire in oxygen gas. In this beautiful exhibition the most brilliant light and the most intense heat are generated, ty the wion of the photogen of the metal and the themogen or the oxysen gas. The metal, having lust its photogen, attracts oxygen gas, and becomes an oxide of iron intensely hested.

The photogen or generator of light in the metal cannot be hydrogen, for " no combinations of iron witl bydrogen or azote are known $t . "$ If this assertion be correct, ve have conbusition without hydrogen.

Sir H. Davy observes, that "the nature of water may be shown synthetically as well as analyticaliy."

"When ten graius of the metai called potassium are added to about two grains of water in a glass tube, there is a violent action, much hydrogen is disengagel, and by heating the results the operation is completed. The same effect is produced upon the potassium, as would be produced by heating it strongly in contact with a small quantity of oxygen; it becomos united to oxvgen, and its increase of weight is in proportion to the weight of the hydrogen as 15 to $2+$."

\footnotetext{
* See Phil Miag vol. riji. n. s7o.

\$ Davy's Elcuntints, p. 2it.

† Dary's Elements, p. 388.
} 
But the composition of water cannot be shown by a compound test. "Potassium inflames when gently heated, aud throws off fumes which are alkaline *." Consequently potassium is a compound of an inflammable clement and a metal, and therefore it may be used as a test to prove that water is a simple body, and not a compound. For the inflammable element and water will form hydrogen gas, and the metal when strongly heated will attract oxygen gas in the sane manner as other metals.

"It may be remarked, that oxygen is mild when in the proportion of 22 per cent. in atmospheric air, and highly coirosive in the proportion of 70 per cent. in nitric acid; or even of that of 40 per cent. in sulphuric acid. How is it, then, that it is found in the ratio of 85 per cent. in water, and that this compound, compared with the others, should be perfectly mild and innocent?" The answer given to this question is, "because its oxygen is so furcilly retained by the hydrogen $\uparrow . "$

Now, as the theory of the compound nature of water does not rest upon common experience, nor upon any known truth, but upon a bare assertion without any proof whatever; therefore, it seems to be nothing more than a fanciful conjecture.

Lynn, Jau. 7, 1814.

Ez. WALKER.

To Messrs. Nicholson and Tilloch.

[To be continued.]

VII. Olservations on a Fiery Meteor. By T. Forster, Esq.

I

Communicate to you the following account of a ficry meteor, which was seen by a friend of mine on Monday evening, the 8 th of November last, about eight o'clock. He was walking between Woodford and Hackney; the weather being fine, and the moon shining bright; and was suddenly surrounded by a light blueish flame: it lasted two or three seconds, so as to give him time to turn himself round and view it on all sides. He felt at the time a warmth like that of a very hot damp day. When it subsided, he perceived the moon much dimmer, on account of the bright light which had just affected the organs of vision. These are all the particulars I have of it, and I communicate them just as they were given me. In hopes that some other persons more distant, who may have seen this curious phænomenon, which is certainly of the ignis fatuzts kind, may give further particulars, I send this for insertion in your Magazine. Yours, \&c.

Clapton, Jan. 10, 1814.

ThOMAS Forster.

P.S. There were many meteors called falling stars on the evening of the aforesaid 8 th of November.

To Messrs. Nicholson and Tilloch.

- Davy's Elements, p. 322.

+ Parkes's Chem. Cat. p. 252. 